\title{
Implementasi Kebijakan Kawasan Tanpa Rokok (KTR) pada Angkutan Umum di Kota Sukabumi (Studi Kasus Angkutan Kota, Trayek Pasar Ramayana-Terminal Jubleg)
}

\author{
Riva Yusdi Maulidya \\ yusdiriva3@gmail.com
}

Program Studi Ilmu Administasi Publik, Universitas Muhammadiyah Sukabumi

\author{
Disubmit \\ 30 Juli 2018
}

\author{
Direvisi \\ 10 Desember 2018 \\ http://dx.doi.org/10.17509/jpis.v27i2.12251
}

Diterima

29 Desember 2018

\begin{abstract}
This research was conducted to determine the inhibiting factors and supporting the implementation of non-smoking areas in the city of Sukabumi by using theories from Van Metter and Van Horn. The approach used in this study is a qualitative approach where the unit of analysis is the Health Office of the city of Sukabumi and the city transportation market route Pasar Ramayana - Terminal Jubleg. In addition to making observations, researchers looking for deeper information by conducting interviews. The results of the study show that the implementation of the nonsmoking area policy on city transportation in the city of Sukabumi has not been fully implemented. The economic environment for cheap cigarettes can be reached by all people. While the characteristics of the implementing agency and the attitude of the policy implementers have been carried out in accordance with the regional regulations on non-smoking areas (KTR) in the city of Sukabumi.
\end{abstract}

Keywords: Policy Implementation, Non-Smoking Area (KTR), and City Transportation

\section{ABSTRAK}

Penelitian ini dilakukan untuk mengetahui faktor penghambat dan pendukung implementasi kawasan tanpa rokok di Kota Sukabumi dengan menggunakan Teori Van Metter dan Van Horn. Pendekatan yang digunakan dalam penelitian ini adalah pendekatan kualitatif dimana unit analisis adalah Dinas Kesehatan kota Sukabumi dan angkutan kota trayek Pasar Ramayana - Terminal Jubleg. Hasil penelitian menunjukan bahwa implementasi kebijakan kawasan tanpa rokok pada angkutan kota di kota Sukabumi belum sepenuhnya berjalan dengan baik. Harga rokok yang murah dapat dijangkau oleh semua masyarakat. Sedangkan karakteristik agen pelaksana dan sikap para pelaksana kebijakan sudah menjalankan sesuai dengan peraturan daerah tentang kawasan tanpa rokok (KTR) di kota Sukabumi.

Kata Kunci: Implementasi Kebijakan, Kawasan Tanpa Rokok (KTR), dan Angkutan Kota

\section{PENDAHULUAN}

Kebiasaan merokok sudah menjadi budaya dalam lingkungan masyarakat sudah tidak asing lagi dengan benda mematikan tersebut. Pada dasarnya merokok itu sangat berbahaya bagi kesehatan. Namun, masyarakat sekarang ini mengkonsumsi rokok sebagai salah satu kebutuhan pokok. Di setiap ruang ditempat umum selalu didapatkan para perokok tanpa memikirkan efek yang ditimbulkan dari 
asap yang mereka buat (Putra, Sudiarta, \& Sarna, 2015). Menghirup asap rokok orang yang tidak merokok lebih berbahaya dibandingkan menghisap rokok sendiri. Resiko bahaya yang harus ditanggung perokok pasif tiga kali lipat dari perokok aktif. Oleh karena itu, perlu dilakukan langkah-langkah pengamanan rokok bagi kesehatan (Atmani \& Rahman, 2013).

Untuk menanggulangi kebiasaan merokok dan perlindungan kesehatan masyarakat dari kebiasaan merokok, pelaksanaan kebijakan Kawasan Tanpa Rokok (KTR) di Kota Sukabumi dilandasi dengan kebijakan yang tertuang dalam Undang-Undang Nomor 36 Tahun 2009 Tentang Kesehatan, PP Nomor 109 Tahun 2012 Tentang Pengamanan Bahan Yang Mengandung Zat Adiktif Berupa Produk Tembakau Bagi Kesehatan, Peraturan Bersama Mentri Kesehatan dan Mentri Dalam Negeri No. 188/Menkes/PB/I/2011 Tentang Pedoman Pelaksanaan KTR. Kota Sukabumi mengeluarkan peraturan daerah Nomor 3 Tahun 2014 Tentang Kawasan Tanpa Rokok (KTR).

Peraturan Daerah ini sudah berjalan selama empat tahun akan tetapi kawasan-kawasan tanpa asap rokok yang meliputi fasilitas pelayanan kesehatan, tempat proses belajar mengajar, tempat anak bermain, tempat ibadah, angkutan umum, dan tempat lainnya itu masih dipertanyakan tindak lanjutnya. Selama peraturan daerah ini diberlakukan belum adanya perkembangan yang optimal bahwa peraturan daerah ini berhasil membuat masyarakat Kota Sukabumi memiliki pola hidup sehat (Nugroho, 2003). Meskipun peraturan daerah tersebut telah disosialisasikan yang dilaksanakan dalam bentuk baligho, spanduk, dan stiker, namun pada kenyataannya semenjak Peraturan daerah tersebut diberlakukan masih adanya perokok yang masih melanggar kebijakan kawasan tanpa rokok, dengan tetap merokok terutama di area yang sudah terdapat tanda larangan merokok.

Proses Implementasi Kawasan Tanpa Rokok di Angkutan Umum di Kota Sukabumi Studi Kasus Angkutan Kota Trayek Pasar Ramayana-Terminal Jubleg belum sesuai dengan apa yang telah ditetapkan. Berdasarkan data primer Angkutan Kota untuk trayek pasar ramayana-terminal jubleg sebanyak 312 unit dari keseluruhan Angkutan Kota berjumlah 2.092 unit. Dari hasil observasi awal, peneliti menemukan permasalahan bahwa dalam pelaksanaan kebijakan Kawasan Tanpa Rokok (KTR) ini sebagai berikut:

\section{Ukuran dan Tujuan Kebijakan}

Tujuannya dibuat kebijakan Peraturan Daerah Nomor 3 Tahun 2014 Kota Sukabumi adalah memberikan perlindungan kesehatan kepada masyarakat dari bahaya asap rokok dan memberikan ruang dan lingkungan yang bersih dan sehat bagi masyarakat. Kemudian yang menjadi ukuran dalam kebijakan tersebut memiliki ukuran hasil yang ingin dicapai dalam kurun waktu jangka pendek dan jangka panjang. Peraturan daerah ini sudah memasuki evaluasi jangka panjang karena sudah berlangsung selama 1-3 tahun. Akan tetapi, perubahan belum bisa dirasakan dikarenakan pengemudi dan penumpang masih ada yang merokok di angkutan kota.

\section{Sumber Daya}

Berdasarkan hasil observasi bersama seksi promosi kesehatan bidang sumber daya kesehatan dan promosi kesehatan bahwa pada Dinas Kesehatan kekurangan Penyidik 
Pegawai Negeri Sipil (PPNS). Saat ini Dinas Kesehatan hanya memiliki satu orang PPNS yaitu pada seksi promosi kesehatan.

\section{Karakteristik Agen Pelaksana}

Dilihat dari sejak diberlakukannya Peraturan Daerah ini belum tegas dalam peneggakan hukumnya. Berdasarkan hasil observasi sejauh ini yang kedapatan merokok di dalam angkutan umum hanya diberikan sosialisasi. Sikap pelaksana kebijakan Kawasan Tanpa Rokok belum menjalankan tugas pokok dan fungsinya masing-masing.

Sikap/Kecenderungan (Disposition) para Pelaksana.

Untuk pimpinan atau penaggung jawab pada Angkutan Umum adalah pemilik angkutan dan pengemudi angkutan kota di Kota Sukabumi. Namun, berdasarkan hasil observasi pengemudi menolak untuk diadakannya kawasan tanpa rokok di angkutan kota.

Komunikasi yang Belum Maksimal Antarorganisasi dan Aktifitas Pelaksana

Dari data primer dapat diketahui bahwa, sosialisasi mengenai kawasan tanpa rokok pada angkutan umum sudah berjalan oleh Dinas Kesehatan pada tahun 2015 yang lalu dalam bentuk kampanye operasi simpatik kawasan tanpa rokok. Sehingga untuk saat ini media sosialisasi yang digunakan menggunakan dalam bentuk stiker yang harus dipasang pada pintu masuk angkutan kota. Namun, angkutan kota sekarang sudah tidak lagi memasang stiker pada pintu masuk. Padahal seperti yang telah dijelaskan dalam peraturan daerah setiap Pimpinan atau Penanggung Jawab wajib membuat dan memasang tanda/petunjuk/peringatan larangan merokok. Oleh karena itu, komunikasi antarorganisasi akan sangat berperan.

Kondisi Eksternal (Ekonomi, Sosial dan Politik)

Maraknya kemunculan berbagai merk rokok dengan harga rokok dari mulai harga paling tinggi sampai harga yang terendah beredar di masyarakat sehingga harganya dapat dijangkau pada semua lapisan masyarakat. Dan kondisi secara ekonomi politik, keberadaan rokok telah memberikan keuntungan bagi pemerintah Kota Sukabumi dalam bentuk pajak iklan reklame rokok sebesar $25 \%$ sebagai salah satu pemasukan pendapatan asli daerah.

Dari fenomena masalah yang telah dipaparkan peneliti tertarik ingin mengetahui bagaimana implementasi kebijakan Kawasan Tanpa Rokok di Kota Sukabumi dan faktor penghambat dan faktor pendukung dari implementasi kebijakan tersebut. Maka peneliti tertarik meneliti permasalahan yang berjudul: "Implementasi Kebijakan Kawasan Tanpa Rokok (KTR) Pada Angkutan Umum di Kota Sukabumi (Studi Kasus Angkutan Umum (Angkutan Kota, Trayek Pasar Ramayana-Terminal Jubleg)".

Adapun tujuan dari penelitian ini adalah sebagai berikut: (1) Mendeskripsikan Kebijakan Kawasan Tanpa Rokok (KTR) di Kota Sukabumi; (2) Mendeskripsikan faktor-faktor pendukung dan penghambat terhadap Kebijakan Kawasan Tanpa Rokok (KTR) di Kota Sukabumi.

\section{KEGUNAAN PENELITIAN}

Manfaat yang diharapkan dari penelitian ini adalah sebagai berikut: (1) Secara teoritis merupakan pengembangan keilmuan yang telah 
diperoleh selama mengikuti perkuliahan tentang ilmu administrasi publik; (2) Dalam wilayah akademis, memperkaya khasanah kajian dasardasar kebijakan publik dan studi implementasi kebijakan publik untuk mengembangkan keilmuan; dan (c) Secara praktis hasil penelitian ini diharapkan dapat memberikan masukan serta kontribusi yang positif bagi Dinas Kesehatan Kota Sukabumi.

\section{TINJAUAN PUSTAKA}

Implementasi kebijakan pada prinsipnya adalah cara agar sebuah kebijakan dapat mencapai tujuannya. Untuk mengimplementasikan kebijakan publik, ada dua pilihan langkah yang ada yaitu langsung mengimplementasikan dalam bentuk program atau melalui formulasi kebijakan derivat atau turunan dari kebijakan publik. Menurut Friedrich (Agustino, 2012) yang mengatakan bahwa kebijakan adalah:

"Serangkaian tindakan /kegiatan yang diusulkan oleh seseorang, kelompok, atau pemerintah dalam suatu lingkungan tertentu dimana terdapat hambatan-hambatan (kesulitan-kesulitan) dan kemungkinan-kemungkinan (kesempatan-kesempatan) dimana kebijakan tersebut diusulkan agar berguna dalam mengatasinya untuk mencapai tujuan yang dimaksud".

Sedangkan, van Meter \& van Horn (Agustino, 2012) mendefinisikan implementasi kebijakan sebagai:

"Tindakan-tindakan yang dilakukan baik oleh individu-individu atau pejabat-pejabat atau kelompokkelompok pemerintah atau swasta yang diarahka pada tercapainya tujuan-tujuan yang telah digariskan dalam keputusa kebijaksanaan". $\begin{array}{lll} & \text { Pada prisip tujuan kebijakan } \\ \text { adalah melakukan } & \text { intervensi }\end{array}$ implementasi kebijakan sebernarnya adalah tindakan dari interventasi itu sendiri. Mazmania dan Sabatier dalam (Nugroho, 2003) memberikan gambaran melakukan intervertasi implementasi kebijakan dalam urutan sebagai berikut:

1. Identifikasi masalah harus diintervensi yaitu melakukan identifikasi terhadap setiap permasalahan yang akan di ambil penyelesaian.

2. Menegaskan tujuan yang hendak dicapai, yaitu mengetahui apa tujuan yang ingin dicapai dari pengembalian suatu kebijakan tersebut.

3. Merancang struktur proses implementasi, yaitu menyusun secara jelas setiap proses pengambilan kebijakan dari pemerintah.

Model pendekatan top-down yang dirumuskan oleh Van Metter dan Van Horn disebut dengan istilah A Model of The Policy Implementation. Proses implementasi ini merupakan sebuah abstraksi atau performasi dari suatu pelaksana kebijakan yang pada dasarnya secara sengaja dilakukan untuk meraih kinerja implementasi kebijakan publik yang tinggi yang berlangsung dalam hubungan dengan berbagai model variabel. Model ini mengandaikan bahwa implementasi kebijakan berjalan secara linier dari keputusan politik yang tersedia, pelaksana, dan kinerja kebijakan publik. Menurut Van Metter \& Van Horn (Agustino, 2012), keberhasilan implementasi kebijakan publik yaitu :

Ukuran dan Tujuan Kebijakan

Implementasi kebijakan dapat diukur tingkat keberhasilannya jika dan 
jika hanya ukuran dan tujuan dari kebijakan memang realistis dengan sosio-kultur yang mengada di tingkat pelaksana kebijakan. Ketika ukuran kebijakan atau tujuan kebijakan terlalu ideal (bahkan terlalu utopis) untuk dilaksanakan di tingkat warga, maka akan sulit merealisasikan kebijakan publik hingga titik yang dapat dikatakan berhasil.

\section{Sumber Daya}

Keberhasilan proses implementasi kebijakan sangat tergantung dari kemampuan memanfaatkan sumber daya yang tersedia. Manusia merupakan sumber daya yang terpenting dalam menentukan suatu keberhasilan proses implementasi. Tahap-tahap tertentu dari keseluruhan proses implementasi menuntut adanya sumber daya yang berkualitas sesuai dengan pekerjaan yang diisyaratkan oleh kebijakan yang telah di tetapkan secara apolitik. Tetapi ketika kompetensi dan kapabilitas dari sumber-sumber daya itu nihil, maka kinerja kebijakan publik sangat sulit untuk diharapkan (Alyakin, 2017).

Tetapi di luar sumber daya manusia, sumber daya lainnya yang perlu diperhitungkan juga ialah sumber daya finansial dan waktu. Ini karena mau tak mau ketika sumber daya manusia yang kompeten dan kapabel telah tersedia sedangkan kucuran dana melalui anggaran tidak tersedia, maka akan timbul masalah untuk merealisasikan apa yang hendak di tuju oleh tujuan kebijakan. Demikian pula halnya dengan sumber daya waktu. Saat sumber daya manusia giat bekerja dan kucuran dana berjalan dengan baik, tetapi terbentur masalah waktu yang terlalu ketat, maka hal ini pun dapat menjadi penyebab ketidak berhasilan suatu implementasi kebijakan. Karena itu sumber daya yang diminta dan dimaksud oleh Van Metter \& van Horn adalah ketiga bentuk sumber daya tersebut.

\section{Karakteristik Agen Pelaksana}

Pusat perhatian pada agen pelaksana meliputi organisasi formal dan organisasi informal yang akan terlibat pengimlementasian kebijakan publik. Hal ini sangat penting karena kinerja implementasi kebijakan (publik) akan sangat mempengaruhi oleh ciri-ciri yang tepat serta cocok dengan para agen pelaksanaannya (Indiahono, 2017). Misalnya, implementasi kebijakan publik yang berusaha untuk merubah perilaku manusia secara radikal, maka agen pelaksana projek itu haruslah berkarakter tegas, keras, dan ketat dalam melaksanakan aturan sesuai dengan sanksi hukum yang telah ditetapkan.

Selain itu, cakupan atau luas wilayah implementasi kebijakan perlu diperhitungkan manakala hendak menetukan agen pelaksana. Semakin luas cakupan implementasi kebijakan, maka seharusnya semakin besar pula agen yang dilibatkan.

Sikap atau kecenderungan (Disposition) para pelaksana.

Sikap penerimaan atau penolakan dari agen pelaksana akan sangat banyak mempengaruhi keberhasilan atau tidaknya implementasi kebijakan publik. Hal ini sangat mungkin terjadi oleh karena kebijakan yang dilaksanakan bukanlah hasil formulasi warga setempat yang mengenal betul persoalan dan permasalahan yang mereka rasakan. Tetapi kebijakan yang akan implementor laksanakan adalah kebijakan 'dari atas' (top down) yang sangat mungkin para pengambil keputusan-nya tidak pernah 
mengetahui (bahkan tidak mampu menyentuh) kebutuhan, keinginan, atau permasalahan yang warga ingin selesaikan.

Komunikasi Antar-Organisasi dan Aktifitas Pelaksana

Koordinasi merupakan mekanisme yang ampuh dalam implementasi pelaksanaan kebijakan publik. Semakin baik koordinasi dan komunikasi di antara pihak-pihak yang terlibat dalam suatu proses implementasi, maka asumsinya kesalahan-kesalahan akan sangat kecil terjadi. Dan, begitu pula sebaliknya.

Lingkungan Ekonomi, Sosial, dan Politik.

Hal terakhir yang perlu juga diperhatikan guna menilai kinerja implementasi publik dalam perspektif yang ditawarkan oleh Van Metter \& Van Horn adalah sejauh mana lingkungan eksternal turut mendorong keberhasilan kebijakan publik yang telah di tetapkan. Lingkungan yang dimaksud termasuk lingkungan sosial, ekonomi, dan politik. Dan lingkungan yang tidak kondusif dapat menjadi biang keladi dari kegagalan implementasi kebijakan. Oleh sebab itu, upaya untuk mengimplementasikan kebijakan harus pula memperhatikan kekondusifan mondisi lingkungan eksternal.

\section{METODELOGI PENELITIAN}

Pendekatan yang digunakan dalam penelitian ini adalah pendekatan kualitatif dimana unit analisis adalah Dinas Kesehatan kota Sukabumi dan angkutan kota trayek Pasar RamayanaTerminal Jubleg. Selain dengan melakukan observasi peneliti menggali informasi dengan cara melakukan wawancara terhadap delapan orang informan terdiri dari Kepala Seksi Promosi Kesehatan, Satuan Polisi
Pamong Praja, Kepala Seksi Angkutan Kota, Pengemudi angkutan kota, dan Penumpang angkutan kota.

HASIL PENELITIAN DAN PEMBAHASAN Ukuran dan Tujuan Kebijakan

Pihak implementor berpendapat bahwa sudah sesuai dengan realita yang ada di lapangan. Selama empat tahun berjalannnya peraturan daerah kawasan tanpa rokok belum optimal karena masih ada yang merokok di dalam angkutan kota. Namun ada dampak positif yaitu masyarakat berani menegur pengemudi angkutan dan penumpang angkutan kota yang merokok didalam angkutan kota. Dilihat dari ukuran dan tujuan kebijakan yaitu memberikan perlindungan kesehatan kepada masyarakat dari bahaya asap rokok dan memberikan ruang dan lingkungan yang bersih dan sehat bagi masyarakat sehingga kegiatan masyarakat di dalam angkutan kota tidak terganggu dari perokok aktif.

\section{Sumber Daya}

Jumlah sumber daya manusia kawasan tanpa rokok ini memiliki jumlah yang cukup memadai. Keberhasilan implementasi kebijakan bukan sumber daya manusia saja tetapi sumber daya finansial dan sumber daya waktu perlu diperhitungkan juga. Karena, mau tidak mau, ketika sumber daya manusia yang kompeten telah tersedia sedangkan alokasi dana untuk implementasi kebijakan kawasan tanpa rokok tidak tersedia maka akan menjadi persoalan untuk merealisasikan tujuan kebijakan publik.

Demikian pula dengan sumber daya waktu. Saat sumber daya manusia giat bekerja dan alokasi dana berjalan dengan baik, tetapi terbentur dengan pesoalan keterbatasan waktu, maka hal ini dapat menjadi penyebebab ketidak 
berhasilan implementasi kebijakan. sumber daya manusia cukup, sedangkan alokasi dana yang diberikan belum memadai dan sumber daya waktu yang terbatas menjadikan penyebab ketidak berhasilan Implementasi Kebijakan Kawasan Tanpa Rokok (KTR) Pada Angkutan Umum di Kota Sukabumi (Studi Kasus Angkutan Kota Trayek Pasar Ramayana-Terminal Jubleg) selama empat tahun berjalan.

\section{Karakteristik Agen Pelaksana}

Karakteristik agen pelaksana sudah menjalankan tugas pokok dan fungsinya masing-masing dilihat dari Dinas Kesehatan yang telah mensosialisasikan dan Satpol PP yang telah melaksanakan operasi kawasan tanpa rokok, namun belum tegas baik dalam pembentukan tim dan aturan atau sanksi hukum. Selain itu, semakin luas cakupan implementasi kebijakan, maka seharusnya semakin besar pula agen yang dilibatkan. Sehingga untuk merubah perilaku masyarakat Kota Sukabumi untuk mencapai tujuan implementasi kebijakan akan tercapai.

\section{Sikap/Kecenderungan Para Pelaksana}

\section{(Disposition)}

Sikap dari para implementor kebijakan sudah memahami dan menerima Peraturan Daerah. Tetapi dilapangan para implementor belum efektif dalam melaksanakan tugas dikarenakan peneliti melihat masih ada perokok yang merokok di dalam angkutan kota dan hasil wawancara dengan pengemudi angkutan kota menolak adanya kawasan tanpa rokok pada angkutan kota.

\section{Komunikasi Antar Organisasi dan Aktivitas Pelaksana}

Implementasi kebijakan yang efektif, sangat ditentukan oleh komunikasi kepada para pelaksana kebijakan secara akurat. Dengan koordinasi merupakan cara yang ampuh dalam implementasi kebijakan. komunikasi antarorganisasi dan kepada angkutan kota trayek pasar ramayanaterminal jubleg belum tersampaikan secara menyeluruh. Semakin baik koordinasi komunikasi di antara pihakpihak yang terlibat dalam implementasi kebijakan, maka kesalahan akan semakin kecil.

\section{Lingkungan Ekonomi, Sosial, dan Politik}

Lingkungan ekonomi, sosial dan politik yang tidak kondusif dapat menjadi kegagalan implementasi kebijakan. Rokok merupakan salah satu kebutuhan sekunder yang menempati posisi primer bagi sebagian kelompok atau kalangan. Ditinjau dari sisi ekonomi merokok adalah salah satu pengeluaran terbesar dari kehidupan para konsumen itu sendiri. Dilihat dari lingkungan ekonomi rumah tangga pengemudi angkutan kota merokok dalam sehari bisa menghabiskan Rp.30.000/per hari dikalikan satu bulan maka hasilnya 30 hari $\times$ Rp. $30.000=$ Rp. 900.000, maka pengemudi angkutan kota dalam satu bulan bisa menghabiskan Rp. 900.000. kemudian pendapatan daerah Kota Sukabumi salah satunya bersumber dari pajak reklame rokok sebesar 25\% diharapkan iklan reklame rokok sudah tidak ada lagi. Namun jikalau reklame iklan rokok tidak ada maka pendapatan daerah akan menurun. Kemudian dari pihak pengusaha rokok juga merasa keberatan dengan adanya peraturan daerah ini karena mereka khawatir kehilangan konsumen. 


\section{Faktor Penghambat dan Faktor Pendukung}

Dalam pelaksanaan kawasan tanpa rokok (KTR) pada angkutan umum di Kota Sukabumi (studi kasus angkutan kota trayek pasar ramayana- terminal jubleg), ditemukan beberapa hal setidaknya akan sedikit mengambat yaitu:

1. Ukuran dan tujuan kebijakan selama empat tahun berjalannya peraturan daerah kawasan tanpa rokok belum optimal karena masih ada yang merokok di dalam angkutan kota.

2. Sumber daya, ditinjau dari sumber daya manusia memadai, namun sumber daya finansial belum memadai dan sumber daya waktu yang terbatas.

3. kurangnya komunikasi yang terjadi antara Dinas kesehatan dan angkutan kota trayek pasar ramayana-terminal jubleg.

4. lingkungan sosial, ekonomi dan politik, hambatan dalan implementasi kebijakan kawasan tanpa rokok yaitu harga rokok yang murah dan dapat dijangkau oleh semua masyarakat.

\section{SIMPULAN}

Berdasarkan hasil penelitian yang telah dideskripsikan mengenai Implementasi Kebijakan Kawasan Tanpa Rokok (KTR) Pada Angkutan Umum Di Kota Sukabumi (Studi Kasus Angkutan Kota Trayek Pasar Ramayana-Terminal Jubleg) belum maksimal masih ada kelemahannya dalam setiap dimensi tersebut, dapat diambil simpulan sebagai berikut:

1. Pada dimensi ukuran dan tujuan kebijakan sudah sangat jelas dipaparkan bahwa angkutan kota diharapkan bebas dari rokok dan perokok tidak mengganggu aktifitas masyarakat di dalam angkutan kota.
Jika ukuran dan tujuan kebijakan belum sesuai harapan maka kebijakan tersebut tidak akan berjalan efektif dan akan menimbulkan kesalahan.

2. Pada dimensi sumber daya sudah memadai dan pelaksana sudah melaksanakan penindakan. Namun, masih ada kelemahan dalam dimensi sumber daya yaitu sumber daya finansial dan sumber daya waktu yang belum memadai.

3. Pada dimensi karakteristik agen pelaksana, adanya kesesuaian agen pelaksana dengan bidangnya. Namun, masih ada kelemahan dalam dimensi karakteristik agen pelaksana yaitu belum terbentuknya tim pembina kawasan tanpa rokok.

5. Pada dimensi sikap/kecenderungan (disposition) para pelaksana, agen pelaksana sudah memahami tentang peraturan kawasan tanapa rokok tersebut akan tetapi kemauan dan respon pengemudi angkutan kota menolak adanya kawasan tanpa rokok di angkutan kota.

6. Pada dimensi komunikasi antarorganisasi dan aktivitas pelaksana belum menyeluruh kaerena belum terbentuknya tim pembina kawasan tanpa rokok di Kota Sukabumi. Komunikasi antara agen pelaksana dengan angkutan kota masih dalam bentuk stiker dan kampanye/sosialisasi pada hari tembakau.

7. Pada dimensi lingkungan ekonomi, sosial, dan politik merokok tidak memandang ekonomi, kelas sosial atas maupun bawah tetap bisa membeli rokok. Dengan dimensi lingkungan ekonomi, sosial, dan politik tersebut, menjadi terhambatnya agen pelaksana 
dalam melaksankan implementasi kawasan tanpa rokok.

\section{REKOMENDASI}

Berdasarkan hasil simpulan diatas ada beberapa saran yang perlu di kemukakan dan direkomendasikan kepada pihak-pihak terkait dengan pelaksanaan kawasan tanpa rokok pada angkutan kota.

1. Agar keberhasilan implementasi kawasan tanpa rokok pada angkutan kota, karena angkutan kota cakupannya luas, maka Dinas Kesehatan Kota Sukabumi harus segera membuat tim kawasan tanpa rokok dimana pengemudi angkutan kota ikut terlibat.

2. Untuk mencapai keberhasilan implementasi kawasan tanpa rokok pada angkutan kota bentuk komunikasinya dalam rangka hari tembakau jangan hanya sosialisasi dengan menempelkan stiker pada angkutan kota, tetapi harus juga memberikan penghargaan kepada angkutan kota yang berhasil menciptakan kawasan tanpa rokok di dalam angkutan kota.

3. Meneggakan sanksi yang sesuai dengan peraturan daerah yang berlaku sehingga masyarakat yang merokok di angkutan kota lebih memahami dan jera untuk merokok di kawasan tersebut. Peneggakan hukum yang baik merupakan faktor yang lebih menentukan dibandingkan dengan rendahnya kesadaran perokok aktif. Karena rendahnya kesadaran perokok bisa ditekan jika peneggakan hukumnya benar.

\section{DAFTAR PUSTAKA}

Agustino, L. (2012). Dasar-Dasar Kebijakan Publik. Bandung: Alfabeta.

Alyakin, R. (2017). Proses dan Analisis Kebijakan Kesehatan (Suatu Pendekatan Konseptual). Yogyakarta: Budi Utama.

Atmani, D. P., \& Rahman, A. (2013). Implementasi Peraturan Daerah Nomor 3 Tahun 2013 Tentang Kawasan Tanpa Rokok (KTR) Pada Kawasan Dinas Kota Semarang. Journal of Public Policy and Management Review, 5(2), 2016. Retrieved from https://ejournal3.undip.ac.id/index. php/jppmr/article/view/11323

Indiahono, D. (2017). Kebijakan Publik. Yogyakarta: Budi Utama.

Nugroho, D. (2003). Kebijakan Publik (Formulasi, Implementasi dan Evaluasi). Jakarta: Gramedia.

Putra, I. G. N. S. A. K. P., Sudiarta, I. K., \& Sarna, K. (2015). Penegakan Hukum Terhadap Kawasan Tanpa Rokok di Kabupaten Badung. Ketha Negara, 4(5), 1-6. Retrieved from https://ojs.unud.ac.id/index.php/Ke rthanegara/article/view/21979 